\title{
Theology of the Mission in Preaching of the Missionary Oblates of Mary Immaculate in the Light of the Encyclical Redemptoris missio
}

\section{Introduction}

The missionary activity of the Church is inscribed in its nature because 'in Christ, the Church is a sacrament, that is, a sign and instrument of the intimate union with God, and the unity of the whole human race' (LG 1). God, conversely, 'wants all people to be saved and to find out the truth' (1 Tim 2:4). Following its calling, the Church fulfills the mission entrusted to it by Jesus Christ, saying, 'Go into the whole world and proclaim the Gospel to every creature! Whoever believes and is baptized will be saved; and whoever does not believe will be condemned' (Mk 16:15-16). Aware of its missionary task, the Church repeatedly reflected on it. One of the most important Church documents dealing with the problem of missions, which appeared after the Second Vatican Council, is undoubtedly John Paul II's encyclical Redemptoris missio.

Apart from theological reflection, systematic pastoral work with liturgical teaching has a very important place in shaping the missionary spirit in all God's people. The purpose of this article is to investigate how the missionary sensitivity

\footnotetext{
${ }^{1}$ Sebastian Wiśniewski OMI - doctor of theological sciences (UPJPII 2012), speech therapist (AMU 2015), graduate of Polish philology in the field of rhetoric (Jagiellonian University 2008), author and editor of books, scientific articles and sermons. Since 2010, a lecturer at the Major Seminary of the Missionary Oblates of Mary Immaculate in Obra at the Faculty of Theology, Adam Mickiewicz University in Poznań. Area of research: preaching, the problem of preached and experienced faith, faith and conversion, Christian perfection, effectiveness of the proclaimed message; e-mail: sebastianw@priest.com. ORCID: 0000-0003-0484-3366.
} 
of the laity is shaped through preaching in the Polish cultural context. The main research source are sermons on missionary topics and missionary themes in other preaching texts, which were included in the collections of sermons of missionaries of the Oblates of Mary Immaculate, and which were published in three Krakow publications: UNUM, WAM and SALWATOR in the years 1998-2019. The analyzed source texts include about five hundred sermons, of which clear mission references are found in 34 units. It accounts for about $7 \%$ of all sermons published by the missionaries of the Oblates of Mary Immaculate in the aforementioned publishing series. The missionary theme is therefore not the leading problem in Oblates' published sermons. Thus, the question about their theological value in the light of the above-mentioned encyclical is even more worth answering.

\section{The Need for a Savior}

The encyclical published on December 7, 1990, began by John Paul II with an important statement that

the mission of Christ the Redeemer, entrusted to the Church, has not yet been fully completed. When we look at humanity at the end of the second millennium after His coming, we find that the mission of the Church is only just the beginning, and that we must put all our energy into its service (RMis 1).

The essence of this mission is to proclaim the Gospel. The Holy Father emphasized the need for missionary activity as it means opening to people the prospect of salvation that comes only from Jesus Christ (see RMis 5). It is a salvation that, obviously, covers the whole person, contrary to the prevailing views that reduce the needs of people to worldly matters (see RMis 11).

The problem outlined by John Paul II is also noticed by the Oblates in their sermons. In one of them, there is even an attempt to make a detailed diagnosis of the condition of modern Europe societies, which - according to the preacher 'slowly plunges into apathy and nihilism [...]. The selfish lifestyle, the absolutization of technology and aggressive consumerism lead to the loss of the soul and the ruin of Christian Europe'. ${ }^{2}$ In another speech, the same author exemplified the attempts of a horizontal search for salvation, 'we will not be saved by our own wisdom and intelligence, scientific and technical achievements, that neither

${ }^{2}$ M. Puchała, Dziś narodzil się Chrystus Pan, Zbawiciel! Homilia wygłoszona na pasterce w bazylice na Świętym Krzyżu, 25 grudnia 2014 roku [in:] Homilie, kazania i mowy okolicznościowe. Homiletyka Misjonarzy Oblatów Maryi Niepokalanej, t. IV (XIII), red. S. Wiśniewski, Kraków 2015, pp. 59. 
democracy, nor tolerance, nor the free market, nor civil rights, nor freedom of speech, nor the European Union will save us. Nobody and nothing but Jesus Christ and His saving power'. ${ }^{3}$

In order to show the necessity to turn to Christ, the Oblates make an effort to build varied oratorical structures. In one of the sermons, for example, three more rhetorical questions appear:

Do we need Christ the Savior today in a world torn by constant wars and conflicts? Do we need Christ today? A savior in a world full of cataclysms, hunger, lies, exploitation and poverty? Do we need Christ the Savior today in a world threatened by the civilization of death ${ }^{4}$ There are also sentences which directly announce that 'today, like two thousand years ago, man still needs a Savior, ${ }^{5}$

about who preachers also speak in the context of the Nativity of the Blessed Virgin Mary. ${ }^{6}$

In the encyclical on missions (see RMis 2), the Pope recalled the statement in his first encyclical, Redemptor Hominis, that Christ the Redeemer 'fully reveals man to man himself' (RH 10), and 'a man who wants to understand himself fully [...], must come closer to Christ' (ibid.). He also spoke prominently about the importance of Jesus Christ's role as the only Savior (see RMis 4-11). In the sermons of the Oblates, the teaching of John Paul II about salvation in Jesus is quoted directly. ${ }^{7}$ However, there is also an approach to the subject of salvation without explicit reference to papal teaching. ${ }^{8}$ The Oblates reach for biblical quotations showing Jesus as the only Savior. ${ }^{9}$ It happens, however, that the preacher quite accidentally introduces a biblical quotation about salvation. This

${ }^{3}$ Id., Człowiek nadal potrzebuje Zbawiciela. Kazanie na pasterke [in:] Homilie, kazania, mowy okolicznościowe, t. IX, red. K. Czepirski, Kraków 2011, pp. 75-78.

${ }^{4}$ Id., Dziś..., p. 59. Cf. also: id., Człowiek..., p. 77.

${ }_{5}^{5}$ Id., Czlowiek..., p. 78.

${ }^{6}$ Cf. J. Bielecki, Kazanie z okazji złożenia ślubów wieczystych $w$ uroczystość Narodzenia Matki Bożej [in:] Misjonarze Oblaci Maryi Niepokalanej, Homilie, kazania, mowy okolicznościowe, Kraków 1998, p. 159.

7 R. Wawrzeniecki, Wiara, która daje chrzest [in:] Co Bóg złączył... Kazania chrzcielne i ślubne misjonarzy oblatów Maryi Niepokalanej, red. S. Wiśniewski, Kraków 2019, p. 17, argues that "everything [...] is concentrated in the basic sentence, 'Jesus Christ is the only Savior of the world and the Redeemer of man. Man cannot be understood without Christ, and man cannot understand himself without Christ', reminds us the Holy Pope John Paul II. And this is a very important thing for us. This truth is to be the basis and goal of our Christian faith".

${ }^{8}$ Cf. W. Zapłata, Kazanie na Międzynarodowy Misyjny Dzień Dziecka [in:] Misjonarze Oblaci Maryi Niepokalanej, Homilie, kazania, mowy okolicznościowe, Kraków 1998, pp. 141-143.

9 J. Chmist, Poza Kościolem nie ma zbawienia. Kazanie o zbawieniu poprzez Kościót [in:] Homilie, kazania, mowy okolicznościowe, t. II, red. K. Czepirski, Kraków 2000, p. 217 argues, for example, that 'we can only be saved through Jesus Christ. This truth is quite clearly stated by 
is the case, for example, in the text in which the author first recalls the horrific images of children murdered in various circumstances and concludes, 'The blood of children murdered by fathers and mothers, doctors and midwives cries out to heaven for vengeance!'. ${ }^{10}$ Immediately after the exclamation, he introduces a rather unforgiving biblical quotation, incorrectly giving its references, 'This is a good and pleasant thing in the eyes of the Savior, our God, who wants all people to be saved, and find out the truth' (Tm 2,1-8). ${ }^{11}$ Immediately after the biblical quotation, the author states, "Today not only the body but also the soul of a child are killed by atheism and hatred'. ${ }^{12}$ Except for a certain linguistic awkwardness revealed in the sermon, it also contains quite a troublesome theological closure in one sentence of the content given in two different semantic areas: naturalistic and metaphorical. While the statement about killing the body is an unequivocal expression, talking about killing the soul falls within the scope of the metaphor.

Speaking about the missionary activity of the Church, John Paul II pointed out that it had only one goal, 'to serve man by showing him the love of God revealed in Jesus Christ' (RMis 2). The Oblates' sermons do not mention this goal. It is rather realized by showing God who wants to save man because He loves him. ${ }^{13}$

In the preaching of Oblate missionaries, it is quite easy to find texts of classical theological origin, such as the sermon in which the author argues about the necessity of belonging to the Church as a condition of salvation,

So if we want to be saved, we must be members of the Mystical Body of Christ, we must somehow belong to the Church of Christ. Thus, not just any, not to what a whim dictates, but to the one, true Church founded by Christ, and for anyone who would not persist in it through his own fault, there is no salvation. For Christ founded His Church that we would be saved through it. To belong to this Church is our duty which we cannot excuse ourselves from. ${ }^{14}$

One might get the impression that the preacher predicts the so-called circles of belonging to the Church, since he speaks of belonging to it 'in some way', but the following sentences dispel doubts in this regard as the author specifies

St. Peter, when $[\ldots]$ he says that you have no salvation in any other, for you have no other name under heaven given to men by which we should be saved (Acts 4:12)'.

${ }^{10}$ W. Zapłata, Kazanie ..., p. 144.

${ }^{11}$ Ibid. The quotation introduced comes actually from $1 \mathrm{Tm} 2: 3-4$.

12 W. Zapłata, Kazanie ..., p. 144.

${ }^{13}$ Cf. S. Wiśniewski, Bóg daje nadzieje w swoim planie zbawienia. Kazanie o nadziei [w:] Homilie, kazania, mowy okolicznościowe, t. IX, red. K. Czepirski, Kraków, p. 252; id., Jezus Pan mój i Zbawiciel. Kazanie o krzyżu [in:] ibid., pp. 268-269; J. Chmist, Poza Kościołem..., p. 216.

${ }^{14}$ J. Chmist, Poza Kościolem..., p. 218. 
that 'visible belonging to the Church is determined [...] by baptism and faith'. ${ }^{15}$ Moreover, the term 'Christ's Church' is for the preacher a synonym for the Roman Catholic Church, as evidenced by the example from the life of St. Augustine, Papini and cardinal Newman, who "spent many years outside the Church in deep internal quandary, seeking the truth, and found their happiness only after finding the Church of Christ'. ${ }^{16}$ The subject of the necessity of the Church was also raised by John Paul II in his encyclical on missionary activity, in which he stated that

Christ gave the Church, His body, the fullness of goods and means of salvation; The Holy Spirit dwells in it, enlivens it with His gifts and charisms, sanctifies it, guides it and constantly renews it. Hence, the special and only one of a kind relationship which, while not excluding the action of Christ and the Spirit beyond the visible borders of the Church, gives it a specific and necessary role (RMis 18).

\section{Persecution of Christians}

When teaching about the missionary activity of the Church, John Paul II noticed that it also included rejection of the Gospel, and even persecution of its preachers. For this reason 'Jesus, before sending the twelve to proclaim the Gospel, instructs them, showing them missionary paths: poverty, meekness, readiness to accept suffering and persecution [...]' (RMis 91). Since persecution is part of the calling of Christ's disciples, they should not face such challenges, as well as misunderstanding or rejection (see RMis 66, 82). However, as the author of Redemptoris missio notes,

the ultimate test is to give the gift of life, up to the acceptance of death, to bear witness to faith in Jesus Christ. As always in the history of Christianity, there have been many martyrs (or witnesses) and they are essential to evangelization. In our time too, there are many bishops, priests, nuns and lay people, often unknown heroes, who give their lives to bear witness to faith. They are heralds and witnesses in the fullest sense of the word (RMis 45).

In preaching of the Oblates, the motive of rejecting the Gospel appears in various contexts. One of the authors refers to the prophecy of Simeon (see Luke 2:34). During his sermon on Maundy Thursday, he encourages us to pray for all priests, bishops, and the pope to have courage and strength to publicly profess faith in Jesus Christ, and to proclaim humbly the unchanging truth of the Gospel,

\footnotetext{
15 Ibid.

16 Ibid., p. 219.
} 
becoming a sign of opposition to the world. ${ }^{17}$ The Oblates also use statistics published by governmental and non-governmental organizations to illustrate the scale of today's persecution of the Church. ${ }^{18}$ The sermons they preach on missionary topics are not limited to theology of missions, but to some extent become a tool for shaping awareness of the situation of Christians in specific places on earth. The audience of sermons can therefore learn in which countries Christ's followers are treated worse than other inhabitants, and in which they are even tortured. ${ }^{19}$ There are also very emotional expressions, such as the one in which the author seems to be exclaiming with his whole being that 'The Church is bleeding like never before! Christianity is the most persecuted religion in the world today. Destroyed churches, houses, murders, tortures, rapes, kidnappings, are common methods of eliminating Christianity. In the Year of Faith, Satan has gone wild' ${ }^{20}$

The Oblates eagerly use the preacher's examples from mission countries, thereby awakening the missionary spirit in their audience. ${ }^{21}$ In the exemplary diversity that is easy to see in sermons on missionary topics, the Oblates also

${ }_{17}$ M. Puchała, Powołani, aby stużyć. Homilia na Wielki Czwartek [in:] Homilie, kazania i mowy okolicznościowe. Homiletyka Misjonarzy Oblatów Maryi Niepokalanej, t. III (XII), red. K. Czepirski, Kraków 2014, p. 86.

18 S. Wiśniewski, Być świadkiem Zmartwychwstatego jak św. Marek Ewangelista [in:] Homilie, kazania i mowy okolicznościowe. Homiletyka Misjonarzy Oblatów Maryi Niepokalanej, t. IV (XIII), red. S. Wiśniewski, Kraków 2015, p. 49 notes, for example, that 'each year about 170,000 Christians die worldwide because of their faith in Jesus Christ!'.

${ }^{19}$ Ibid., pp. 49-50, there is information that 'Christians today are being persecuted in Asia, the Middle East and North Africa, where Muslim Sharia law is being introduced. It applies, inter alia, to Saudi Arabia, Sudan, Libya, Nigeria; for some time it was also used in Afghanistan. [...] In Nigeria, 11,000 Christians have been murdered since the introduction of Sharia law'. Similarly, R. Wawrzeniecki, I ty jesteś odpowiedzialny za misje Kościoła. Kazanie na niedzielę misyjna [in:] Homilie, kazania, mowy okolicznościowe, t. IV, red. K. Czepirski, Kraków 2002, pp. 67-68, makes the audience aware that 'one of the martyrs is Bishop Benjamin de Jesus, Oblate of Mary Immaculate, working in the Philippines. He was murdered in front of his cathedral as he got out of the car. In a similar vein, M. Puchała, Kazanie powołaniowe [in:] Misjonarze Oblaci Maryi Niepokalanej, Homilie, kazania, mowy okolicznościowe, Kraków 1998, p. 152, notes that, 'According to Vatican sources, 68 missionaries died as martyrs in 1997 alone in mission countries. Among them, Bishop Benjamin - the Oblate of Mary Immaculate, Bishop of the Diocese of Jolo in the Philippines, who was shot at the door of his cathedral. A man of peace and reconciliation - as John Paul II described him'. Cf. also, K. Nering, Świadectwo wiary Piotra i Pawła przykładem dla wspótczesnego chrześcijanina. Kazanie na uroczystość Piotra i Pawła, 29 czerwca [in:] Homilie, kazania i mowy okolicznościowe, red. K. Czepirski, Kraków 2012, p. 76.

${ }^{20}$ J. Kowalik, Cała prawda o Chrystusie. Kazanie na Uroczystość Chrystusa Króla Wszechświata [in:] Homilie, kazania i mowy okolicznościowe. Homiletyka Misjonarzy Oblatów Maryi Niepokalanej, t. III (XII), red. K. Czepirski, Kraków 2014, p. 68.

${ }^{21}$ Cf. e.g.: P. Furman, Tu się wszystko zaczęło. Nauka na dzień odnowienia przyrzeczeń chrztu świętego [in:] Homilie, kazania i mowy okolicznościowe, red. K. Czepirski, Kraków 2012, p. 185; S. Wiśniewski, Nie bój się, wierz tylko! (Mk 5,36). Kazanie prymicyjne w Dzień Pięćdziesiątnicy [in:] ibid., pp. 145-146; id., Kapłan ukryty w Sercu Jezusa. Kazanie prymicyjne w uroczystość 
reach for the poignant testimonies of contemporary heroes of faith from the period of persecution in the Union of Soviet Socialist Republics ${ }^{22}$ and other countries where communist authorities brutally fought against the Church. ${ }^{23}$ Among the examples of persecution of the Church today, one can find even very eloquent personal testimonies given by the preacher. ${ }^{24}$ The statistics quoted in this context cease to be an ordinary information carrier, and gain the value of a strong influence on the recipient's emotions. This is the case, for example, in the sermon of an Oblate from Ukraine, who tells about the painful fate of the Catholics persecuted there,

Until recently, in my country, people wanted to throw faith out of everyone's heart. Over 300,000 churches were blown up with dynamite, they were turned

Trójcy Świętej [in:] ibid., pp. 153-154; P. Lepich, Modlitwa jako szkoła nadziei. Kazanie o modlitwie [in:] ibid., p. 195.

${ }_{22}$ M. Puchała, Powotani..., p. 84, for example, quotes the sad fate of the Church in Ukraine, 'Bishop Józef Slipyj was arrested in 1945 by the NKVD after his refusal to convert to Orthodoxy. For 18 years he was imprisoned in Siberian labor camps, bravely enduring beatings, hunger and hard physical labor. Thanks to the extraordinary commitment of Pope John XXIII, he was released from Siberia and deported to Rome [...]'.

${ }^{23}$ Id., Wdzięczni Bogu za Eucharystię. Homilia na Wielki Czwartek. Siedlce, 2 kwietnia 2014 roku [in:] Homilie, kazania i mowy okolicznościowe. Homiletyka Misjonarzy Oblatów Maryi Niepokalanej, t. IV (XIII), red. S. Wiśniewski, Kraków 2015, pp. 81-83, for example, introduces in his sermon the testimony of 'Father Anton Luli, a 86-year-old Albanian Jesuit, who spent 42 years in communist prisons and labor camps, subjected to elaborate torture and humiliation'. S. Łuszczki, Kapłaństwo jest dla was! Kazanie na Wielki Czwartek [in:] Homilie, kazania i mowy okolicznościowe, red. K. Czepirski, Kraków 2012, p. 91, also deals with persecution of the Church and notes that 'in 1917 communism was born - an ideology with devilish roots. It is estimated that under Russian rule alone, the Bolsheviks murdered 100,000 Catholic and Orthodox priests. In 1936, the Masonic Revolution broke out in Spain. 6,500 priests and monks were killed. They were hanged by their hands, and had crosses cut out on their backs - everyone was watching and applauding! In November 2008, Pope Benedict XVI canonized 498 martyrs of this persecution. Another 500 of God's servants are waiting for their beatification. Among them there are 22 of our fellow Oblates in Spain [...]'.

${ }^{24}$ P. Wyszkowski, Kazanie na Niedzielę Misyjna [in:] Misjonarze Oblaci Maryi Niepokalanej, Homilie, kazania, mowy okolicznościowe, Kraków 1998, pp. 131-132 confesses, 'The fact that I am here is the merit of my mother who has always taught me deep faith. I had $8 \mathrm{~km}$ to the church and despite the fact that there was a state ban which forbade children under 18 even to enter the church doorstep, my mother took me to the church every Sunday, in mud, rain and snow along dirty roads. And when I couldn't walk, I was little, my legs ached, she took me on my back and carried me. Until now, I remember those maternal roads and backs. And when we gathered in front of the closed church doors, and the authorities came, my parents hid me in the bushes, covered me with a cloth so that I would not be taken to an orphanage. I remember how, during the All Saints' procession, the authorities threw glass and stones at us, pulled out candles and beat people with candles on their heads. It was hard, but we persevered because my parents taught that you had to always suffer for faith'. 
into factories, tractor repair plants, stables. Over 45 thousand bishops and priests were crucified in prison cells, they were poured with water in winter and frozen, thrown into steam boilers. ${ }^{25}$

A difficult situation of the Church in countries where it cannot exercise its freedom calls for missionary sensitivity of all Catholics. In accordance with the intention expressed in the papal teaching on missions, the Church should awaken the awareness of each Catholic's responsibility for missions.

\section{Awakening Responsibility for Missions}

Persecution and, in general, suffering, which is an inseparable companion of the mission, encourage all the faithful to offer up their personal difficult experiences for the mission. The encyclical Redemptoris missio contains the instruction that 'the salvific value of all suffering, accepted and offered to God with love, flows from the sacrifice of Christ, who calls upon the members of His Mystical Body to share in His sufferings; to «make up for deficiencies in His own body» (cf. Col 1:24)' (RMis 78). This extraordinary dimension of suffering in the missionary context also appears in the preaching reflection of the Oblates. ${ }^{26}$

The encyclical of John Paul II on the missionary activity of the Church contains the important statement that 'prayer should accompany missionaries on their path so that the proclamation of the Word may be effective by God's grace' (RMis 78). In the following sentences, the Pope expresses the conviction that

the missionary in his sacrifice should be accompanied and supported by the faithful with their own sacrifice. Therefore, I am asking all those who minister to the sick to educate them about the salvific value of suffering and encourage them to offer it to God as missionaries. Through this sacrifice they also become missionaries themselves [...] (RMis 78).

The Oblates refer directly to these encouragements of the Pope, inviting to the missionary commitment 'through prayer, suffering and the gift of the heart'. ${ }^{27}$

${ }^{25}$ Ibid., p. 131.

${ }^{26}$ Cf.: A. Bochm, Wzór odwagi $i$ wiary. Kazanie odpustowe ku czci Świętego Marcina. 11 listopada [in:] Homilie, kazania i mowy okolicznościowe. Homiletyka Misjonarzy Oblatów Maryi Niepokalanej, t. III (XII), red. K. Czepirski, Kraków 2014, p. 25; R. Wawrzeniecki, I ty..., p. 67; J. Różański, Homilia na Misyjny Dzień Chorych. 11 lutego [in:] Misjonarze Oblaci Maryi Niepokalanej, Homilie, kazania, mowy okolicznościowe, Kraków 1998, p. 137.

${ }^{27}$ S. Wiśniewski, Trwać przy Jezusie. Homilia o misjach do Przyjaciół Misji [in:] Homilie, kazania, mowy okolicznościowe, t. VIII, red. K. Czepirski, Kraków 2006, p. 177. Cf. also: 
Moreover, the Oblates propose joining the group of Friends of the Mission, the Papal Missionary Works and the Papal Work of Promoting Faith, which they also directly manifest in their sermons.$^{28}$ The encouragement to pray for missions was expressed through thanks for it as well. ${ }^{29}$

An important element in supporting the mission of the Church is the personal missionary commitment of each of the faithful. It happens both through the word and through the witness of the Gospel life. John Paul II pointed to the need to bear witness to his faith, stating that 'those who are included in the Catholic Church should feel privileged, and thus more obliged to bear witness to the faith and Christian life as a service to their brothers and sisters, and a due response to God' (RMis 11). An opportunity to give testimony is created, among others, by - as John Paul II notices - economic migration, because 'looking for work today forces many Christians from young communities to go to areas where Christianity is unknown, and sometimes rejected or persecuted. [...] These circumstances undoubtedly provide a good opportunity to live the faith and bear witness to it' (RMis 82). The audience of the Oblates' sermons also learn about this dimension of the mission. ${ }^{30}$

John Paul II, referring to the teaching of the Second Vatican Council expressed in the decree on the missionary activity of the Church (Ad gentes), pointed to the clear relationship that exists between the mission of the Church and the holiness of its members (see RMis 77, 90-91). The Oblates in their sermons also use the key linking mission and holiness, introducing edifying examples of saints who did not hesitate to give their lives for the Gospel, and showing how Christians are to carry out their heroism in their lives today. ${ }^{31}$ One of the preachers notes

M. Puchała, Kazanie..., pp. 153-154; M. Szafors, Świat potrzebuje przewodnika - Chrystusa Dobrego Pasterza i Jego kapłanów. Kazanie o powołaniu [in:] Homilie, kazania, mowy okolicznościowe, t. IX, red. K. Czepirski, Kraków 2011, p. 135.

${ }^{28}$ Cf. W. Zapłata, Kazanie..., p. 148; R. Wawrzeniecki, I ty..., pp. 68-70.

${ }^{29}$ Cf. S. Łuszczki, Kapłaństwo..., p. 94.

${ }^{30}$ Cf. A. Bochm, Przygotować droge Chrystusowi. Kazanie odpustowe z okazji Narodzenia Świętego Jana Chrzciciela. 24 sierpnia [in:] Homilie, kazania i mowy okolicznościowe. Homiletyka Misjonarzy Oblatów Maryi Niepokalanej, t. III (XII), red. K. Czepirski, Kraków 2014, pp. 15-16; P. Wyszkowski, Kazanie..., p. 133; S. Wiśniewski, Maryja — Wielki Świadek Bożych Tajemnic. Maryjne kazanie odpustowe, 15 sierpnia [in:] Homilie, kazania i mowy okolicznościowe, red. K. Czepirski, Kraków 2012, p. 41; id., „Pozwólcie dzieciom przychodzić do Mnie” [in:] Co Bóg złaczyt... Kazania chrzcielne i ślubne misjonarzy oblatów Maryi Niepokalanej, red. S. Wiśniewski, Kraków 2019, p. 10; K. Nering, Świadectwo..., p. 77; F. Wieczorek, Nosimy w sobie światto Chrystusa, aby nasze życie było świadectwem [in:] Homilie, kazania i mowy okolicznościowe, red. K. Czepirski, Kraków 2012, p. 88; R. Wawrzeniecki, I ty..., p. 66; M. Puchała, Powołani ..., p. 86; id., Ja jestem z wami. Homilia na uroczystość Wniebowstapienia Pańskiego [in:] Homilie, kazania, mowy okolicznościowe, t. V, Kraków 2003, pp. 69-70.

${ }_{31}$ A. Bochm, Przygotować..., p. 15, states, for example, that St. John the Baptist 'remains faithful to his mission until he gives his life'. 
that e.g. St. John the Baptist 'with his words, but also with his life says: this is the Lamb of God, he points to Jesus, testifies of Him'. ${ }^{32}$ The Oblate derives an exhortation from this attitude, 'Our task is also to point to Jesus. How can we do this? First of all, through the testimony of our life. Sometimes we are surprised that many people leave the Church, that young people stop going to church. But maybe because we are not always witnesses of the Risen Christ'. ${ }^{33}$ The author also uses the popularized preacher's quotation from Evangelii nuntiandi, without avoiding the impoverishing modification of papal teaching and states that 'Pope Paul VI said that today's world did not need teachers, but witnesses, and if it listened to teachers, then only if they were witnesses' ${ }^{34}$ It is noteworthy that Paul VI expressed his thought differently in the exhortation mentioned, without questioning the necessity of teaching, 'the man of our time listens more willingly to witnesses than to teachers; and if he listens to teachers, it is because they are witnesses' (EN 41).

An indulgence in honor of the Assumption of the Blessed Virgin Mary becomes an occasion to raise awareness of the necessity of evangelization. In the sermon for that day, one of the Oblates, referring to the gospel scene of the visitation of St. Elisabeth through Mary, argued that 'the Holy Mother is the first Apostle. She goes in haste to bear witness to the Good News, to God's Gospel! This proclamation of great works of God is until today the first and most important duty of the Church and of every Christian' ${ }^{35}$ The Oblates do not shy away from very specific examples to motivate their listeners to participate in the missionary activity of the Church. It happens that in the sermon there is even a bitter reproach made to the audience, through which the preacher wants to achieve a positive result, i.e. greater missionary commitment of his listeners. ${ }^{36}$

The need to become witnesses of Christ is an important task not only for laity but also for monks. ${ }^{37}$ One of the provincial superiors emphasized this in his sermon to the seminarians during the Mass on the occasion of the beginning of the academic year,

Studying theology is not visiting a museum [...], but falling in love with Christ, transforming your life in imitation of Christ! And all this, Beloved Brothers, to be a true witness, to devote oneself to the total service of God, the Church and other

32 Ibid., p. 12.

${ }^{33}$ Ibid.

${ }^{34}$ Ibid.

${ }_{35}$ S. Wiśniewski, Maryja ..., p. 41.

${ }^{36}$ Cf. ibid., pp. 41-42.

${ }^{37}$ Cf. M. Wrzos, Wezwani, aby „rodzić” Chrystusa. Homilia na uroczystość Świętej Bożej Rodzicielki Maryi [in:] Homilie, kazania, mowy okolicznościowe, t. VII, red. K. Czepirski, Kraków 2004, pp. 156-159. 
people. All this to proclaim the Good News to pagans, to light up and bring the fire of truth to the whole world, to enlighten the light of Christ's truth for modern man. ${ }^{38}$

A specific feature of the Oblates' awakening of responsibility for missions is the reference to the missionary ethos and showing still too few missionary priests. ${ }^{39}$

\section{Conclusion}

Preachers from the Congregation of the Missionary Oblates of Mary Immaculate, in the texts that appeared in the collections published in the years 1998-2019, take up selected thoughts from the encyclical Redemptoris missio, presenting them in the key of sensitizing recipients to the need for missionary commitment. The theological level of sermons of the Oblates in the perspective of the missionary activity of the Church lacks in-depth reflection on the importance of conversion, and receiving the sacrament of holy baptism, the meaning of which was clearly shown in the encyclical on missions by John Paul II (see RMis 46-50, 59). Undoubtedly, it would also be valuable to preach the challenges of inculturation processes (see RMis 52-54), and to present the papal teaching about the kingdom of God, which has an important place in the message of the encyclical Redemptoris missio (see RMis 12-20). The preaching of the Oblates on missionary problems could certainly be enriched with a pneumahagic dimension, which the author of the encyclical notes and develops in the next ten points (see RMis 21-30).

Despite the fact that some theological issues were not included in the preaching message of the Oblates, they nevertheless make a considerable effort to shape the recipients' mission awareness. The theological value of undertaken missionary issues is clear in the Oblate sermons, and coincides with the reflection expressed by John Paul II in the encyclical Redemptoris missio. On the basis of the researched source material, it is possible to determine main events of the preaching of the Oblates on the missionary activity of the Church. The first is to proclaim salvation in Jesus Christ, and show Him as the only Savior of man. The second emphasis is pointing to the important role of the Church in the work of salvation, through the implementation of Christ's missionary mandate. Another

38 J. Bielecki, Homilia Prowincjała na rozpoczęcie roku akademickiego w Wyższym Seminarium Duchownym Misjonarzy Oblatów Maryi Niepokalanej w Obrze [in:] Misjonarze Oblaci Maryi Niepokalanej, Homilie, kazania, mowy okolicznościowe, Kraków 1998, pp. 156-157.

${ }^{39}$ Cf. M. Szafors, Świat ..., pp. 130-135; P. Kościanek, Kapłana nikt nie może zastapić. Kazanie na Niedziele Dobrego Pasterza [in:] Homilie, kazania i mowy okolicznościowe. Homiletyka Misjonarzy Oblatów Maryi Niepokalanej, t. III (XII), red. K. Czepirski, Kraków 2014, p. 64; W. Zapłata, Kazanie..., pp. 146-147. 
preaching feature is showing the important role of missionaries who are ready to give their lives for Christ, and testify to the Gospel many times with their blood, because the Church is persecuted in many places in the world. Hence, the appeal for the support of the mission by all Catholics who, through prayers, sufferings and witness of Christian life offered to God, will join the mission of the Church.

\section{Teologia misji w kaznodziejstwie misjonarzy oblatów MN w świetle encykliki Redemptoris missio}

\section{Streszczenie}

Kościół nieustannie odpowiada na wezwanie do ewangelizacji, ponieważ jest świadom obowiązku misyjnego. Teologicznej refleksji dotyczącej misji Kościoła została poświęcona encyklika Jana Pawła II pt. Redemptoris missio. W niniejszym artykule została podjęta próba zbadania, w jakim zakresie to papieskie nauczanie jest podejmowane w kaznodziejstwie misjonarzy oblatów Maryi Niepokalanej. Autor wskazuje na obszary tematyczne encykliki, do których nawiązują w swoim przepowiadaniu oblaci, i prezentuje zagadnienia, których wyraźnie brakuje w publikowanych tekstach kazań.

\section{Słowa kluczowe}

teologia misji, kaznodziejstwo misjonarzy oblatów MN, nauczanie Jana Pawła II

\section{Keywords}

Mission Theology, preaching of the Missionary Oblates of Mary Immaculate, teaching of John Paul II

\section{Bibliography}

Bielecki J., Homilia Prowincjała na rozpoczęcie roku akademickiego w Wyższym Seminarium Duchownym Misjonarzy Oblatów Maryi Niepokalanej w Obrze [in:] Misjonarze Oblaci Maryi Niepokalanej, Homilie, kazania, mowy okolicznościowe, Kraków 1998, pp. 154-159.

Bielecki J., Kazanie z okazji złożenia ślubów wieczystych w uroczystość Narodzenia Matki Bożej [in:] Misjonarze Oblaci Maryi Niepokalanej, Homilie, kazania, mowy okolicznościowe, Kraków 1998, pp. 159-163.

Bochm A., Przygotować droge Chrystusowi. Kazanie odpustowe z okazji Narodzenia Świętego Jana Chrzciciela. 24 sierpnia [in:] Homilie, kazania i mowy okolicznościowe. Homiletyka Misjonarzy Oblatów Maryi Niepokalanej, t. II (XII), red. K. Czepirski, Kraków 2014, pp. 11-19. 
Bochm A., Wzór odwagi i wiary. Kazanie odpustowe ku czci Świętego Marcina. 11 listopada [in:] Homilie, kazania i mowy okolicznościowe. Homiletyka Misjonarzy Oblatów Maryi Niepokalanej, t. III (XII), red. K. Czepirski, Kraków 2014.

Chmist J., Poza Kościołem nie ma zbawienia. Kazanie o zbawieniu poprzez Kościót [in:] Homilie, kazania, mowy okolicznościowe, t. II, red. K. Czepirski, Kraków 2000, pp. 216-220.

Czepirski K., Ochrzczeni Duchem Świętym. Kazanie do Mszy Świętej o NMP z Wieczernika [in:] Homilie, kazania i mowy okolicznościowe. Homiletyka Misjonarzy Oblatów Maryi Niepokalanej, t. (XIII), red. S. Wiśniewski, Kraków 2015, pp. 7-12.

Encyklika „Redemptor hominis” Ojca świętego Jana Pawła II w której u początku swej papieskiej postugi zwraca się do czcigodnych braci w biskupstwie, do kapłanów, do rodzin zakonnych, do drogich synów i córek Kościoła oraz do wszystkich ludzi dobrej woli [in:] Encykliki Ojca świętego Jana Pawła II, t. 1, Wydawnictwo św. Stanisława B.M. Archidiecezji Krakowskiej, Wydawnictwo M, Kraków [n.d.], pp. 1-53.

Encyklika „Redemptoris missio” Ojca świętego Jana Pawła II o stałej aktualności postania misyjnego [in:] Encykliki Ojca świętego Jana Pawła II, t. 1, Wydawnictwo św. Stanisława B.M. Archidiecezji Krakowskiej, Wydawnictwo M, Kraków [n.d.], pp. $377-460$.

Furman P., Tu się wszystko zaczęło. Nauka na dzień odnowienia przyrzeczeń chrztu świętego [in:] Homilie, kazania i mowy okolicznościowe, red. K. Czepirski, Kraków 2012, pp. 184-187.

Kościanek P., Kapłana nikt nie może zastapić. Kazanie na Niedziele Dobrego Pasterza [in:] Homilie, kazania i mowy okolicznościowe. Homiletyka Misjonarzy Oblatów Maryi Niepokalanej, t. III (XII), red. K. Czepirski, Kraków 2014, pp. 62-65.

Kowalik J., Cała prawda o Chrystusie. Kazanie na Uroczystość Chrystusa Króla Wszechświata, w: Homilie, kazania i mowy okolicznościowe. Homiletyka Misjonarzy Oblatów Maryi Niepokalanej, t. III (XII), red. K. Czepirski, Kraków 2014, pp. 66-71.

Lepich P., Modlitwa jako szkoła nadziei. Kazanie o modlitwie [in:] Homilie, kazania i mowy okolicznościowe, red. K. Czepirski, Kraków 2012, pp. 192-197.

Łuszczki S., Kapłaństwo jest dla was! Kazanie na Wielki Czwartek [in:] Homilie, kazania i mowy okolicznościowe, red. K. Czepirski, Kraków 2012, pp. 89-94.

Nering K., Świadectwo wiary Piotra i Pawła przykładem dla współczesnego chrześcijanina. Kazanie na uroczystość Piotra i Pawła, 29 czerwca [in:] Homilie, kazania i mowy okolicznościowe, red. K. Czepirski, Kraków 2012, pp. 75-78.

Paweł VI, Adhortacja apostolska „Evangelii nuntiandi” o ewangelizacji wświecie współczesnym. Do biskupów, kapłanów i wiernych całego Kościoła katolickiego, 8.12.1975, https://opoka.org.pl/biblioteka/W/WP/pawel_vi/adhortacje/evangelii_ nuntiandi.html.

Puchała M., Człowiek nadal potrzebuje Zbawiciela. Kazanie na pasterke [in:] Homilie, kazania, mowy okolicznościowe, t. IX, red. K. Czepirski, Kraków 2011, pp. 75-78. 
Puchała M., Dziś narodził się Chrystus Pan, Zbawiciel! Homilia wygłoszona na pasterce w bazylice na Świętym Krzyżu, 25 grudnia 2014 roku [in:] Homilie, kazania i mowy okolicznościowe. Homiletyka Misjonarzy Oblatów Maryi Niepokalanej, t. IV (XIII), red. S. Wiśniewski, Kraków 2015, pp. 57-60.

Puchała M., Ja jestem z wami. Homilia na uroczystość Wniebowstapienia Pańskiego [in:] Homilie, kazania, mowy okolicznościowe, t. V, Kraków 2003, pp. 67-71.

Puchała M., Kazanie powołaniowe [in:] Misjonarze Oblaci Maryi Niepokalanej, Homilie, kazania, mowy okolicznościowe, Kraków 1998, pp. 150-154.

Puchała M., Powołani, aby stużyć. Homilia na Wielki Czwartek [in:] Homilie, kazania i mowy okolicznościowe. Homiletyka Misjonarzy Oblatów Maryi Niepokalanej, t. III (XII), red. K. Czepirski, Kraków 2014, pp. 83-86.

Puchała M., Wdzięczni Bogu za Eucharystię. Homilia na Wielki Czwartek. Siedlce, 2 kwietnia 2014 roku [in:] Homilie, kazania i mowy okolicznościowe. Homiletyka Misjonarzy Oblatów Maryi Niepokalanej, t. IV (XIII), red. S. Wiśniewski, Kraków 2015, pp. 78-84.

Różański J., Homilia na Misyjny Dzień Chorych. 11 lutego [in:] Misjonarze Oblaci Maryi Niepokalanej, Homilie, kazania, mowy okolicznościowe, Kraków 1998, pp. 134-140.

Szafors M., Świat potrzebuje przewodnika - Chrystusa Dobrego Pasterza i Jego kapłanów. Kazanie o powołaniu [in:] Homilie, kazania, mowy okolicznościowe, t. IX, red. K. Czepirski, Kraków 2011, pp. 130-135.

Wawrzeniecki R., I ty jesteś odpowiedzialny za misje Kościoła. Kazanie na niedzielę misyjna [in:] Homilie, kazania, mowy okolicznościowe, t. IV, red. K. Czepirski, Kraków 2002, pp. 66-70.

Wawrzeniecki R., Wiara, która daje chrzest [in:] Co Bóg złączyt... Kazania chrzcielne i ślubne misjonarzy oblatów Maryi Niepokalanej, red. S. Wiśniewski, Kraków 2019, pp. 16-23.

Wieczorek F., Nosimy w sobie światto Chrystusa, aby nasze życie było świadectwem [in:] Homilie, kazania i mowy okolicznościowe, red. K. Czepirski, Kraków 2012, pp. 85-88.

Wiśniewski S., Bóg daje nadzieję w swoim planie zbawienia. Kazanie o nadziei [in:] Homilie, kazania, mowy okolicznościowe, t. IX, red. K. Czepirski, Kraków 2011, pp. 251-260.

Wiśniewski S., Być świadkiem Zmartwychwstałego jak św. Marek Ewangelista [in:] Homilie, kazania i mowy okolicznościowe. Homiletyka Misjonarzy Oblatów Maryi Niepokalanej, t. IV (XIII), red. S. Wiśniewski, Kraków 2015, pp. 48-52.

Wiśniewski S., Jezus — Pan mój i Zbawiciel. Kazanie o krzyżu [in:] Homilie, kazania, mowy okolicznościowe, t. IX, red. K. Czepirski, Kraków 2011, pp. 261-269.

Wiśniewski S., Kapłan ukryty w Sercu Jezusa. Kazanie prymicyjne w uroczystość Trójcy Świętej [in:] Homilie, kazania i mowy okolicznościowe, red. K. Czepirski, Kraków 2012, pp. 150-155. 
Wiśniewski S., Maryja - Wielki Świadek Bożych Tajemnic. Maryjne kazanie odpustowe, 15 sierpnia [in:] Homilie, kazania i mowy okolicznościowe, red. K. Czepirski, Kraków 2012, pp. 39-44.

Wiśniewski S., Nie bój się, wierz tylko! (Mk 5,36). Kazanie prymicyjne w Dzień Pięćdziesiąnicy [in:] Homilie, kazania i mowy okolicznościowe, red. K. Czepirski, Kraków 2012, pp. 145-149.

Wiśniewski S., „Pozwólcie dzieciom przychodzić do Mnie” [in:] Co Bóg złaczył... Kazania chrzcielne i ślubne misjonarzy oblatów Maryi Niepokalanej, red. S. Wiśniewski, Kraków 2019, pp. 9-11.

Wiśniewski S., Trwać przy Jezusie. Homilia o misjach do Przyjaciół Misji [in:] Homilie, kazania, mowy okolicznościowe, t. VIII, red. K. Czepirski, Kraków 2006, pp. 176181.

Wrzos M., Wezwani, aby „rodzič” Chrystusa. Homilia na uroczystość Świętej Bożej Rodzicielki Maryi [in:] Homilie, kazania, mowy okolicznościowe, t. VII, red. K. Czepirski, Kraków 2004, pp. 156-159.

Wyszkowski P., Kazanie na Niedziele Misyjna [in:] Misjonarze Oblaci Maryi Niepokalanej, Homilie, kazania, mowy okolicznościowe, Kraków 1998, pp. 130-133.

Zapłata W., Kazanie na Międzynarodowy Misyjny Dzień Dziecka [in:] Misjonarze Oblaci Maryi Niepokalanej, Homilie, kazania, mowy okolicznościowe, Kraków 1998, pp. 141-149. 